\title{
Altered colonic environment, a possible predisposition to colorectal cancer and colonic inflammatory bowel disease: Rationale of dietary manipulation with emphasis on disaccharides
}

A Szilagyi MD FRCPC

\begin{abstract}
A Szilagyi. Altered colonic environment, a possible predisposition to colorectal cancer and colonic inflammatory bowel disease: Rationale of dietary manipulation with emphasis on disaccharides. Can J Gastroenterol 1998;12(2):133-146. A recurrent theme in the schema of pathogenetic mechanisms attributed to colorectal cancer (CRC) and inflammatory bowel disease (IBD) is the interaction between genes and environment. Dietary and other environmental factors, and lower intestinal flora and their chemical interactions occur in the pathogenesis of both. Events at the mucosal surface may be influenced by factors in the luminal environment and by contributions of the host. In addition, both forms of IBD - Crohn's disease (CD) and ulcerative colitis (UC) - have distinctive associated host events. Even within $\mathrm{CD}$ and UC, different clinical patterns and prognoses may have different specific host mechanisms. Some of the current putative pathogenetic processes in CRC and IBD are reviewed. Particular attention is given to hypotheses relating to the role of dietetic substances, mainly fibre and dairy products, and how they may affect disease formation. It is argued that within the context of hypotheses proposed for possible beneficial effects of these two dietetic factors, CRC and IBD may be considered together. Further support is
\end{abstract}

lent to arguments that similar and additional hypothetical features ascribed to beneficial effects of fibre may be attributed to disaccharides, lactose and its derivatives, lactulose and lactitol.

Key Words: Colonic environment, Colorectal cancer, Crohn's disease, Dietary manipulation, Disaccharides, Inflammatory bowel disease, Ulcerative colitis Altération du milieu colonique, prédisposition
possible au cancer rectocolique et à la maladie
inflammatoire de l'intestin : raison d'être de la
diétothérapie avec accent sur les disaccharides
RÉSUMÉ : L'un des thèmes qui reviennent souvent lorsqu'on aborde les
mécanismes pathologiques du cancer rectocolique (CRC) et la maladie
inflammatoire de l'intestin (MII) est l'interaction entre les gènes et le
milieu. Certains facteurs diététiques, d'autres facteurs liés au milieu, la
présence d'une flore intestinale moindre et les interactions chimiques
entre tous ces facteurs contribuent à la pathogenèse des deux. Les lésions
superficielles de la muqueuse peuvent subir l'influence de facteurs du
voir page suivante

Division of Gastroenterology, Department of Medicine, The Sir Mortimer B Davis Jewish General Hospital, Faculty of Medicine,

Correspondence and reprints: Dr A Szilagyi, 6000 Côte des Neiges, \#100, Montreal, Quebec H3S 128. Telephone 514-739-7370, fax 514-340-8282

Received for publication August 12, 1997. Accepted December 8, 1997 
milieu luminal et de certains facteurs liés à l'hôte. De plus, les deux formes de MII, la maladie de Crohn (MC) et la colite ulcéreuse (CU), comportent des traits liés à l'hôte. Même dans la $\mathrm{MC}$ et la $\mathrm{CU}$, différents pronostics cliniques peuvent découler de mécanismes différents, propres à l'hôte. On passe ici en revue certains des processus pathologiques potentiels envisagés à l'heure actuelle dans le CRC et les MII. On accorde une attention particulière aux hypothèses portant sur le rôle des aliments, fibres et produits laitiers surtout, dans l'installation de la maladie. Selon certains, dans les hypothèses avancées au sujet des effets bienfaisants possibles de ces deux facteurs diététiques, on peut regrouper le CRC et les MII. On tend à appuyer les hypothèses selon lesquelles les disaccharides, le lactose et ses dérivés, le lactulose et le lacritol, pourraient avoir des propriétés semblables à celles qui permettent aux fibres de produire leurs effets bienfaisants, et d'autres propriétés encore.
A recurrent theme in the schema of pathogenetic mechanisms attributed to colorectal cancer (CRC) and inflammatory bowel disease (IBD) is the interaction between genes and environment. Variables such as geographic location, urban or rural setting and shifting economics appear to be important in both diseases. Dietary and other environmental factors, and lower intestinal flora and their chemical interactions occur in the pathogenesis of both. Events at the mucosal surface may be influenced by factors in the luminal environment and by contributions of the host. Such molecular abnormalities concerning mucus production or type of mucus $(1,2)$, protective goblet cell-derived trefoil peptides (3), heat shock proteins (1), nitrous oxide (4) and intestinal enzyme production (5) can be driven by either luminal (colonic environment) or host factors. Right-sided, left-sided and rectal cancer (CA) may be associated with different etiological and epidemiological factors (6-8). In addition, both forms of IBD - Crohn's disease (CD) and ulcerative colitis (UC) - have distinctive associated host events. Even within CD and UC, we surmise that different clinical patterns and prognoses may have different specific host mechanisms. In both CRC and IBD, genetic alterations may involve germline mutations (9-12). Somatic alterations may be involved in CRC $(12,13)$, and there may be human leukocyte antigen (HLA) II-dependent alterations with major influences on the immune response in IBD (1).

This article reviews some of the current putative pathogenetic processes in CRC and IBD. Particular attention is given to hypotheses relating to the role of dietetic substances, mainly fibre and dairy products, and how they may affect disease formation. It is argued that within the context of hypotheses proposed for possible beneficial effects of these two dietetic factors, CRC and IBD may be considered together. We also lend further support to arguments that similar and additional hypothetical features ascribed to beneficial effects of fibre may be attributed to disaccharides, lactose and its derivatives, lactulose and lactitol. It is the goal of the review to provide a framework on which to build potential clinical trials to test such a hypothesis.

\section{EPIDEMIOLOGY OF CRC AND IBD}

The distribution of CRC, CD and UC generally follows, with some exceptions, a pattern of low prevalence and incidence in countries near the equator (eg, low CRC rate in Finland and high CRC rate in Singapore) (Table 1) (7, 14,15). Rates of CRC tend to increase among immigrants going from low risk to high risk areas (7), and decrease in those migrating from high risk to low risk areas (16). A simi-

\section{TABLE 1}

Comparison of similarities between colorectal cancer (CRC) and inflammatory bowel disease (IBD) (Crohn's disease [CD] or ulcerative colitis [UC])

\begin{tabular}{|c|c|}
\hline Epidemiology & Pathogenic similarities \\
\hline $\begin{array}{l}\text { Diminished prevalence and } \\
\text { incidence towards the } \\
\text { equator }\end{array}$ & $\begin{array}{l}\text { Influence of diet (CRC, CD; unclear in } \\
\text { de novo UC) }\end{array}$ \\
\hline $\begin{array}{l}\text { Parallel changes in incidence } \\
\text { in migrants }\end{array}$ & $\begin{array}{l}\text { Influence of lower intestinal } \\
\text { microflora }(C R C, C D, \cup C)\end{array}$ \\
\hline $\begin{array}{r}\text { Parallel rise in incidence } \\
\text { with industrialization }\end{array}$ & $\begin{array}{l}\text { Existence of model in which disease } \\
\text { does not occur in absence of } \\
\text { bacteria }\end{array}$ \\
\hline $\begin{array}{l}\text { Parallel rise in incidence } \\
\text { with urbanization }\end{array}$ & Mucosal barrier abnormalities \\
\hline Parallel cluster origins & $\begin{array}{l}\text { Genetic predisposition (albeit different } \\
\text { in } C R C, C D, \cup C \text { ) }\end{array}$ \\
\hline
\end{tabular}

lar pattern sometimes occurs in $\operatorname{IBD}(15,17,18)$, although it is less often reported. Within countries there is also a variation from rural to urban centres such that urbanization increases rates of CRC (7) and possibly IBD (14). In Japan, a country with formerly a low incidence and prevalence of both CRC and IBD, increasing disease rates have been more recently reported $(8,15)$. There has been an overall rise in the incidence of CRC in North America, comprising a modest decrease in Caucasians but a more dramatic rise among African Americans (5). Similarly, in North America there has been increasing rates of $\mathrm{CD}$ but a relatively steady rate of UC $(14,15)$.

An interesting observation was made on rates of IBD in Jewish patients in Los Angeles. There was a disproportionate number of subjects whose origins were from middle Europe (roughly corresponding to Romania and the former Czechoslovakia) (19). Independent observers also reported a high incidence of CRC among descendants (ethnicity not specified) of Bohemia Moravia living in the midwestern United States (20). In addition, the Jewish population is also thought to have an increased risk of CRC (16).

Although the epidemiological relationship between CRC and IBD could be coincidental, coinheritance of a genetic predisposition or exposure to environmental agents in early life could also explain such a coexisting source. In either case, geographic variation and parallelism in rates with progressive industrialization suggest influence of environmental factors. A comparison of conceptual pathogenetic differences between CRC and IBD is shown in Table 2. 


\section{PATHOGENESIS OF CRC}

CRC may be regarded as the end result of a progressive increase in colonocyte proliferation and loss of cellular control due to complex interaction among promoters and inhibitors (21). Different stages in development can be traced from expanded DNA synthesis and subsequent migration of proliferative zones in crypts as described by Lipkin (22). Occasionally foci of aberrant crypts are seen as sources of dysplasia but most cases of CRC arise in western cultures through adenoma carcinoma sequence (21). Where flat cancers of the colon, as described from Japan, fit into current postulates of CRC formation and whether they exist in western populations are not clear (23).

The entire colonic mucosa in patients with adenoma (24) or familial polyposis syndrome (25) is in a state of hyperproliferation. In rats, increasing colonic proliferation is seen with ageing (26). A similar explanation may contribute to the steep rise in CRC observed after the age 50 years in humans. Each stage is accompanied by distinct chromosomal aberrations as described by Fearon and Vogelstein (12) and Vogelstein et al (27) although the total accumulation of mutations is most important. The process may be hastened in familial adenoma cases that have a left-sided predominance of cancer formation (6).

Other germline mutations in mismatch repair genes are the cause of right-sided lesions in hereditary nonpolyposis colorectal cancer (HNPCC) syndrome (28). In these cases there is a predominance of right-sided lesions. However, the presence of such mutations is not an invariable predictor of carcinoma formation. Some $20 \%$ of documented subjects with HNPCC do not develop cancer by age 80 years (29). Thus, in these latter two conditions - hyperproliferation and germline mutations - which represent about $5 \%$ to $7 \%$ of all $\mathrm{CRC}$, a very high likelihood of cancer formation is inherited. An additional $15 \%$ to $20 \%$ of those with sporadic CRC may also have a genetic predisposition (28). Such sporadic genetic influence may follow a pattern of site-specific cancers similar to nonsporadic cases (6).

In low prevalence areas, right-sided disease predominates, while in regions of high endemicity and industrialization left-sided disease is more common, with a steady shift to more proximal locations. Left-sided cancers may be more affected by diet than right-sided cases, as was recently suggested by Liberman and colleagues (30). In their study, rats fed a mixture of foods usually eaten by adenoma patients showed increased left-sided colonocyte proliferation. A recent Finnish study suggested that genetic polymorphism of apolipoprotein E, particularly the $\mathrm{E} 4$ phenotype, may be protective against right-sided colon cancers (31).

Burkitt (32) popularized the observation that a diet high in insoluble fibre, as consumed by many rural Africans, may be protective against CRC and other colonic diseases. The original hypothesis linked increased fecal weights in Africans with protective influences. Indeed, more recently, low fecal weight was associated with a higher risk of CRC (33). It was subsequently shown that diets high in animal fat and red meat are associated with increased risk of colon cancer
TABLE 2

Comparison of conceptual pathogenetic differences between colorectal cancer and inflammatory bowel disease*

\begin{tabular}{lc}
\hline Colorectal cancer & Inflammatory bowel disease \\
\hline $\begin{array}{l}\text { Usually older onset } \\
\text { Inherited or acquired } \\
\text { chromosomal abnormalities } \\
\text { of proto-oncogene or } \\
\text { suppressor genes or DNA } \\
\text { mismatch repair genes }\end{array}$ & $\begin{array}{c}\text { Usually younger onset } \\
\text { Possible inheritance of } \\
\text { histocompatible lymphocyte } \\
\text { antigen types }\end{array}$ \\
$\begin{array}{l}\text { Progressive loss of control of } \\
\text { cellular apoptosis and } \\
\text { proliferation }\end{array}$ & $\begin{array}{c}\text { Activation of inflammatory process } \\
\text { with humoral dominance in }\end{array}$ \\
ulcerative colitis, and cellular \\
Chromosomal damage & Uncominance in Crohn's disease \\
& with subsequent tissue damage \\
\hline
\end{tabular}

${ }^{*}$ Colorectal cancer (CRC) in inflammatory bowel disease is associated with genetic abnormalities similar to those in sporadic CRC. Sequences may, however, differ, and additional chromosomal abnormalities may subsequently be dominant

$(34,35)$. The effect of fat, however, depends on its type. For example, fish oils $(36,37)$, olive oil $(8,35)$ and fresh fruits and vegetables are associated with a moderate protective effect (5). In fact, it is possible that many of the protective effects of high fibre diets are due to low fat, low meat or other antineoplastic agents found in fresh fruits and vegetables (5).

Although the epidemiology of right-sided CA, left-sided CA and rectal CA may vary (8), most studies do not differentiate the effects of various diets. Consequently, in this report the effects of diet on all three sites will be referred to, except where specifically indicated otherwise. The putative benefits of crude insoluble fibres are related to increased colonic transit, which diminishes contact time of preestablished or established carcinogens; dilution of possible carcinogens due to the high water holding capacity of undigested fibre; altered bacterial flora; altered fecal $\mathrm{pH}$, which could precipitate bile salts or interfere with its metabolism; and enhanced production of short chain fatty acids (SCFAs) $(38,39)$. These latter three effects will be further elucidated.

Initial efforts to determine why differences exist in CRC epidemiology examined the role of colonic microflora. Hill et al (40) proposed that environmental agents or bile salts are converted by bacteria into carcinogens. Different colonic flora were identified in low risk Africans compared with high risk westerners (41). However, in the United States, no colonic flora differences were found between Seventh Day Adventists, who consume large numbers of vegetables, and others consuming a more typical western diet (42). Bacteroides and other anaerobes together with increased fecal steroids have been reported in western subjects $(41,43,44)$, and these changes are accompanied by increased fecal betaglucuronidase (45). The best example of the role of bacterial carcinogen formation was reported by Lacquer who showed that neutral cycasin is converted by intestinal bacteria to methylazoxymethanol, a carcinogen (7). Some subjects on a western diet were found to have mutagens in their stool (8). 
More recently, the specific association of Streptococcus bovis with CRC (and possibly with adenomas) was described $(46,47)$. In conjunction with a report of increased methane production in CRC patients, which decreases following resection (48), these observations lend credence to the possible role of bacteria to CRC initiation or promotion.

The carcinogenic role of bile salts was also suggested by Hill and co-workers (40) who theorized that bacteria can convert deoxycholic acid to 20-methylcholanthrene, a carcinogen. Although this hypothesis has not been proven, the findings of, first, elevated deoxycholic acid levels in the serum of adenoma patients compared with controls (49) and, second, receptors for deoxycholic acid in cancerous but not normal tissue (50) suggest a pathogenic role of this bile salt in CRC formation. Moreover, increased steady exposure of colonic mucosa to bile salts, such as occurs after cholecystectomy, may enhance the risk of right-sided CRC (51). Experimentally it was shown that a high fat, low fibre diet in rats was associated with the highest risk of tumour formation after induction by azoxymethane. Low fibre diets were associated with the highest fecal bile acid concentrations, indirectly supporting the ability of fibre to lower fecal bile acids (52). There is also evidence that fecal bile salts are correlated with adenoma size, colonocyte proliferative rate and activated protein kinase C (53). This latter enzyme is thought to be an important regulator of colonocyte proliferation (54). In addition, in mice, bile acids can lead to proliferation of microbes with mutagenic potential, leading to a favourable environment for cancer formation because hyperproliferative mucosa is more susceptible to the effects of mutagens (8).

SCFAs (propionate, butyrate and acetate) are also products of bacterial metabolism of any undigested carbohydrate reaching the colon $(39,55,56)$. In particular $\mathrm{N}$-butyrate has been found to be specifically and preferentially metabolized by colonocytes (57). Capacity to metabolize this SCFA clearly is affected by bacterial presence (58). The effect of butyrate has been variably reported to enhance $(59,60)$ or inhibit (61) colonocyte proliferation, particularly in cell cultures derived from neoplastic cells (62).

A recent study (63) and editorial (64) helped to clarify confusion about the dual role of butyrate in normal and neoplastic colonocytes. Hass et al (63) reported that, in the absence of butyrate, significant apoptosis occurs in association with an elevation of Bax protein (a known inducer of apoptosis). An editorial by Hague et al (64) reviewed the available literature, noting that in carcinoma cell lines, butyrate inhibits proliferation and promotes colonocyte differentiation, which leads via bak protein to enhanced apoptosis. Several mechanisms for this seemingly dual effect were offered (64).

The beneficial influence of fibre has not been easy to prove or disprove. Studies using animal have reported benefit (65$67)$ and no benefit $(68,69)$. The theoretical benefits of a high fibre diet have also been difficult to prove in epidemiological studies. The reasons include different methodological approaches, the myriad potential social and cultural con- founding factors and the probability that not all fibres are of equal benefit. A number of older studies showed either a weak inverse effect or no effect of fibre on CRC (8). A Scandinavian study of brewery workers showed that CRC was prevented by a high fibre diet despite a fourfold increase in beer consumption compared with average beer consumers (70).

CRC incidence is now rising in Japan. However, in the late 1970s CRC prevalence was low in Japan compared with western countries. Ironically, it was then reported that fibre intake was not different in Japan compared with Britain (71). Indirect suggestion that fibre is inversely related to CRC is concluded from the following observations. Patients with diverticulosis, another fibre deficiency disease (32), are at increased risk of colon cancer (72). In addition, patients who have had polyps removed are found to be efficient starch absorbers, with about 50\% less unabsorbed starch than nonpatients (73).

Reasons for the different conclusions of studies on fibre and CRC include that different fibres have different effects (74). For example, wheat bran, versus other types of bran, may reach the distal colon, providing more butyrate (75). Also, the type of bran in breads was shown to influence bile acid saponification, with rye having the most efficient effect (76), and there may be an inverse correlation between ease of fibre fermentability and its protection against CRC (77). But, clearly, because of the variables mentioned above and the different putative effects of fibre, the association between fibre and CRC needs further clarification. Nevertheless, Read (38) states that a high fibre diet is probably beneficial. This opinion was also reinforced by a reanalysis of 13 case control studies confirming a strong negative association between diets that contain high fibre and cancer risk (78).

\section{PATHOGENESIS OF IBD}

The putative mechanisms of the etiology and pathogenesis of IBD are very complex. Sartor (1) states that IBD represents "a progressive series of separate events from induction and perpetuation of inflammation with multiple immunoregulatory abnormalities and a final common pathway of tissue injury". As others have stated, the existence of multiple models, each of which reproduces features of IBD, argues that we are likely dealing with $\mathrm{CD}$ and ulcerative colitides in the pathogenesis of IBD. A historical perspective on IBD emphasizes the level of immunological controls in these diseases (79). A number of reviews on the subject have been recently published (80-82). Infectious agents that can mimic IBD (83-87) also emphasize that idiopathic colitides may still be caused by other unidentified agents.

There is an increased familial incidence of IBD that suggests a genetic predisposition $(88,89)$. However, clustering of cases may also imply infectious etiology $(90,91)$. The HLAII antigens DR2 in perinuclear antineutrophil cytoplasmic antibody (pANCA)-positive UC and DR4 in pANCAnegative cases are reported (92), while in CD, HLADR1 and DQW5 are predominant, with others found as well $(1,81)$. Occasionally pANCA-positive cases are found in CD (93). The type of immunoregulatory dysfunction is related to UC 
and CD. Humoral mediated anti-inflammatory Th2 dysfunction predominates in UC, while pro-inflammatory Th1 cellular function is abnormal in CD (1). These immunological dysfunctions are accentuated by factors that regulate the barrier function of the intestinal mucosa. For example, increased permeability of mucosa may be found in CD patients and their family members (94). There are also abnormal trefoil peptides in CD (3) and abnormal mucin in UC, both of which are products of goblet cells. The former may be abnormal in CD (3) while the latter may be abnormal in UC (95).

Abnormalities in the normal protective mechanisms that separate the humoral contents from the host may be instrumental in either causing or perpetuating the disease and observed immunological activation. The search for specific pathogens has led to the elimination of most contenders except Mycobacterium paratuberculosis, Listeria monocytogenes and the measles virus (1). Perpetuation or relapses, however, have been associated with bacterial infections, childhood upper respiratory or enteric viral infections, or antibiotics (96-101).

Of 18 models reviewed by Elson et al (102), 11 tested the role of environmental factors and two probably variable interaction (102). In all 13 models the resident microflora without a specific pathogen - may be involved in initiating or perpetuating disease. For example, the role of Bacteroides vulgatus in activating carageenin-induced colitis is one of the best examples of environmental microflora interaction (103). Johnson et al (104) reported the most comprehensive model to date using the cotton-top tamarin model of UC to demonstrate the interaction of environment and host. Cotton-top tamarins spontaneously develop an acute colitis resembling idiopathic UC in captivity and go on to develop CRC. Using three controlled environments and three experimental diets in each category (normal, high fat and high fibre) the authors showed that the development of acute colitis, progression and recurrence were environmentally related. Disease was least likely to occur in an isolated environment. However, no diet was protective against observed chronic colonic changes and progression to CRC.

Clinical studies examining microfloral differences in IBD showed several alterations in fecal cultures. A study comparing the mucosa-associated microflora of patients with the microflora of newly diagnosed UC patients, relapsed UC patients or those in remission from UC, found reduced obligate anaerobes during active disease. When these patients were treated, numbers of bifidobacteria, eubacteria, clostridia and lactobacilli approached levels found in those with quiescent disease (105).

In $\mathrm{CD}$, coliforms are increased and anaerobes are relatively unchanged (106). In another study, fecal cultures of $\mathrm{CD}$ patients were found to have reduced bifidobacteria, but not bacteroides or lactobacilli (107). The recurrence of CD after bowel resection reportedly depends on reestablishment of the fecal stream (108), and this finding in particular supports the notion that bacteria or bacterial products are important in inducing or maintaining disease. Van de Merwe et al (109) even suggested that anaerobic Gram-positive cocci in family members of patients are indigenous and may predispose them to the development of disease. Moreover, antibiotics, both in experimental models (110) and in clinical practice, appear to be of benefit treating $\operatorname{IBD}(111,112)$.

SCFAs in UC have an interesting role. Roediger (113) initially hypothesized that colonocytes are in the starved state in UC. There is an increasing gradient from right to left of dependency on N-butyrate of colonocytes as fuel (113, 114). However, in UC, even in remission, there is an abnormality of colonocyte utilization of butyrate (115). This selectively predisposes colitis to begin or remain on the left side. In cotton-top tamarins and humans with UC there is an inverse relationship among more severe disease, fecal SCFA and fecal $\mathrm{pH}$ (116-118). The low $\mathrm{pH}$ can also inhibit bacterial metabolism (119). In addition, Roediger et al (120) proposed that the presence of hydrogen sulphide-producing bacteria contributes to inhibition of SCFA production.

Based on these findings a number of trials using either $\mathrm{N}$-butyrate or a mixture of SCFA enemas have been reported (121-123). The general trend is that SCFA are successful in improving clinical symptoms and histological scores.

A long term complication of either UC or CD colitis is the development of CRC. The risk is initially highest with long standing extensive UC, but the risk with distal UC catches up by the fourth decade (124). The presence of sclerosing cholangitis may impose a further risk $(125,126)$. This form of CRC is different from sporadic CRC only in that there is a more uniform colonic distribution and that regular polyps and flat areas with dysplasia occur (124). Cancers arise at an earlier age than in sporadic cases. However, in other ways CRC in UC is similar to sporadic cases. Rectal biopsies from UC patients in remission show an expanded proliferative pattern compared with that in normals $(127,128)$. Similar findings are observed after ileorectal anastomosis (129). Whether a similar pattern occurs in Crohn's colitis is unclear because increased proliferation was not found in $\mathrm{CD}$ patients compared with adenoma or CRC patients (24). Concentration of fecal bile acids was increased in both UC and CD patients $(130,131)$, elevating the risk of CRC. In experimentally induced colitis, butyrate enemas reduced both azoxymethane-induced tumour formation and accompanying increased colonocyte proliferation (132).

Genetic abnormalities in UC-related CRC occur in a manner similar to that in sporadic CRC. These abnormalities reflect both familial adenomatous polyposis and HNPCC chromosomal abnormalities and mismatch repair gene errors (133-135). p53 abnormalities, which are normally late events in sporadic CRC, occur earlier in UC-related CRC than in sporadic CRC (136).

The role of diet in causation or management of IBD remains unclear and controversial. Early studies on examining various nutritional components in CD found diminished fibre, decreased fresh fruit and vegetable intake and increased consumption of refined sugar in CD patients' diets (137). Others found no change in fibre but increased sugar consumption (138). High fibre and unrefined carbohydrate diet was reported to be beneficial in a small group of $C D$ patients 
compared retrospectively with a group of matched controls (139). However, this diet did not work in a small group of patients with UC (140) nor in a group of CD patients, compared with elimination diets (141). Nonstenosing CD patients from Italy who ate a low residue diet fared no differently than a group of similar patients allowed to eat ad libitum (142). Complete removal of food in active disease might heal CD if the primary insult were a food antigen.

In the 1970s and early 1980s, total parenteral nutrition was reported to be beneficial as primary treatment in CD patients with different anatomical locations (143-145). However, the concept of bowel rest as being important for primary healing was dispelled by a study from Greenberg et al (146). They showed that there was no statistically significant difference in comparing total or partial parenteral nutrition or defined formula diets with regards to remission rates. Relapses also occurred approximately equally in the groups. Nevertheless, such therapy may work in conjunction with standard medical treatment $(147,148)$.

Elemental diets, particularly in children, have been shown to be more successful in maintaining remissions in CD $(149,150)$ and may serve an adjunctive role in UC (151). Because elemental diets are more easily absorbed in the small bowel and are hypoallergenic, the implication is that whole protein may be instrumental in perpetuating inflammation or that elemental diets alter bacterial flora (150). Studies on eliminating possible offending foods from diet in an effort to maintain remission have been published. A multicentre British study compared corticosteroids with an elimination diet. The study conducted over two years found a significant difference in clinical improvement and length of remission with diet versus corticosteroid therapy. From the clinical perspective the benefit was $17 \%$ in favour of the elimination diet (152). However, in another study of CD patients only 12 of 80 patients $(15 \%)$ had a double-blind rechallenge-proven food sensitivity. Those authors concluded that food sensitivity was of insufficient importance to test all subjects with this disease (153).

Since the early 1990s polymeric enteral diets using whole proteins have been evaluated. These diets have also been found to be as effective as elemental diets in inducing remission (154). Anti-inflammatory diets rich in fish oil have been reported to improve corticosteroid response and clinical features of IBD (155-157). The putative mechanism of effect is via inhibition of leukotriene B4 production. However, recent clinical trials using zileuton or another specific inhibitor of leukotriene were not successful as the sole therapy for UC $(158,159)$. Cancer and dysplasia may be affected by folic acid supplementation, which improves hypomethylation. Methylation of nucleic acids is instrumental in DNA repair (160).

\section{DISACCHARIDES AND DAIRY PRODUCTS}

Disaccharides can reproduce many of the biochemical effects attributed to a high fibre diet. The protective benefits of fibre are most clearly delineated in studies where dietary rather than supplemental fibres are evaluated (5). Although the observation raises the likelihood that other factors in fruits and vegetables are antiproliferative, the individual components attributed to fibre clearly still play a role in reducing abnormal colonic events.

Three disaccharides - lactose (glucose and galactose), lactulose (fructose galactose) and lactitol (galactoside glucitol) - may all have similar effects in the lower intestine. All three disaccharides are equally efficacious in treating hepatic encephalopathy (161). With lactulose, cecal effluent and stool $\mathrm{pH}$ are decreased, while SCFAs are increased; colonic flora may be altered, although total aerobic or anaerobic species do not change quantitatively $(162,163)$. In germ-free rats, effects induced by lactulose do not occur (164). Furthermore, feeding encapsulated lactobacilli strains to hepatic encephalopathy patients also reproduces therapeutic effects (165). These observations are important because they demonstrate the impact of all three disaccharides on microflora on a particular disease outcome. Most of the putative changes may also be relevant to possible therapeutic effects on CRC or colitis.

Florent et al (162) showed that, in human volunteers fed $20 \mathrm{~g}$ lactulose bid, cecal SCFAs increased, stool $\mathrm{pH}$ decreased and breath hydrogen measurements decreased. In addition, fecal beta-galactosidase levels rose significantly (162). Continuous daily feeding of lactulose leads to increased fecal bifidobacteria and decreased levels of Clostridium perfringens and bacteroides (166). As well, prolonged feeding of small doses of lactulose reduces the severity of symptoms when larger doses are administered (167). The combined observation of decreased measured exhaled hydrogen and elevated fecal beta-galactosidase, coupled with salvaged calories (168) and micronutrient absorption (169), is representative of colonic adaptation to maldigested carbohydrate that reaches the colon.

The same phenomenon is observed with continued lactose in the presence of lactose intolerance. Reports of improved symptoms to continued lactose consumption surfaced in the 1970s from different underdeveloped countries provided with milk powder by the United Nations (170, 171). However, in the past decade the mechanism of colonic adaptation was further elucidated. Hertzler and Savaiano (172) recently reported that adaptation to lactose occurs rapidly within two weeks; these researchers felt that reduction in measured hydrogen was due to decreased production because of altered microbial flora. Emergence of bifidobacteria, which does not produce hydrogen, may account for reduced measured hydrogen (173). Adaptation as defined herein can also occur in the absence of obvious disaccharide utilization. Recently, it was reported that colonic adaptation in subjects with short gut syndrome and retained colon occurred without associated dairy consumption (174). Colonic adaptation also does not occur with every sugar. For example, there is no evidence of improvement in tolerance to fructose (175).

Adaptation is thus associated with low fecal $\mathrm{pH}$, increases in some SCFAs and altered microbial flora. These are similar to factors thought to be important in the benefits attributed 
to fibre. In fact, a protective effect of lactulose against colonic carcinogens has been described. The effect was attributed to decreased deoxycholate absorption, possibly via accelerated transit, and lowered fecal $\mathrm{pH}$ (176). However, short term daily ingestion of lactulose also leads to decreased fecal beta-glucuronidase and other enzymes thought to be involved in carcinogen formation (166). Lactose in lactose maldigesters likely mimics these changes. However, the only study comparing fecal SCFAs in lactose-tolerant and -intolerant subjects yielded varying results (177). In that study, isobutyric and isovaleric acid (derived from maldigested protein) were increased in tolerant maldigesters. Although tolerant maldigesters consumed almost twice as much daily milk as intolerant subjects, the difference between the two groups was not statistically significant. Further, bacterial adaptation was not strictly evaluated, and the possible role of methanogenic bacteria, which reduce hydrogen production, could also have accounted for differences in tolerance (178). Increased production of SCFA with increased absorption could also have been missed. This adaptive response of the colon to undigested carbohydrate may be beneficial in preventing a hyperproliferative mucosa. Because adaptation is clearly associated with change in microbial function or metabolism, it is reasonable to attempt to alter colonic flora as a primary event (Table 3 ).

Efforts to alter colonic flora have recently been outlined by Marteau and Rambaud (179). Fermented milk containing Lactobacillus acidophilus was shown to alter fecal bile acids significantly, particularly in those with colon cancer (180), as well as altering several enzymes such as nitroreductase and beta-glucosidase, which may be important in colorectal carcinogenesis (181). When L acidophilus is fed to patients (by adding it to milk), the observed biochemical changes last four weeks (181). However, beta-galactosidase was not increased in stool when fermented products are given (182). Findings of similar benefit with bifidobacteria prompted Hertzler et al (173) to suggest that lactose-intolerant sub-
TABLE 3

Proposed effects of altered colonic flora via feeding patients lactobacilli

Altered fecal bile acids

Altered nitroreductase

Altered beta glucuronidase

Protection against methotrexate-induced colitis

No increased fecal beta galactosidase

jects be adapted to dairy consumption instead of withdrawal or modification. In view of the aforementioned findings, this suggestion seems reasonable and complements some earlier opinions on the usefulness of acidification of stool in lactose maldigesters $(8,183)$. The putative effects of fibre, dairy and disaccharides on colonic environment are compared in Table 4 .

There is considerable debate about the role of dairy products in relation to CRC. The current basic problem is that there are at least two diametrically opposite components to consider. While high fat dairy products may be harmful, their high calcium content may be considered beneficial. Calcium is postulated to inhibit expanded colonocyte proliferation (184) and to reduce the colonization ability of pathogens (185). Unfortunately, regarding a protective role of supplemental calcium in CRC formation, some studies report benefit $(186,187)$ but others do not $(188-190)$. In the studies reporting benefit $(186,187)$, the labelling index of proliferating colonic epithelium was reduced by dietary calcium supplements. Two of the three studies that found no benefit used supplemental calcium, and both were randomized and double-blind $(188,189)$. The third study in that group showed no influence of supplemental calcium on rat colonocyte labelling index (190).

More recently, the combined effect of calcium and phosphates on precipitating bile salts has been recognized (191).

TABLE 4

Comparison of the potential benefits of disaccharides (lactose, lactulose, lactitol), fibre, dairy foods and disaccharides

\begin{tabular}{lll}
\hline Disaccharides & Fibre & Dairy products \\
\hline Increased intestinal transit & Increased intestinal transit & $\begin{array}{c}\text { Calcium and phosphate intake inhibitory to } \\
\text { abnormal colonocyte proliferation }\end{array}$ \\
$\begin{array}{c}\text { Early increase in colonic transit may be negated } \\
\text { by adaptation }\end{array}$ & Dilution of potential carcinogens \\
$\begin{array}{l}\text { Decreased stool pH } \\
\text { Increased fecal beta-galactosidase }\end{array}$ & Altered bacterial flora \\
$\begin{array}{c}\text { Increased fecal bifidobacteria, and decreased } \\
\text { clostridia and bacteroides species }\end{array}$ & $\begin{array}{c}\text { Precipitation of bile salts } \\
\text { acids (butyrate, propionate, acetate) }\end{array}$ & $\begin{array}{c}\text { Calcium may inhibit pathogen colonization } \\
\text { maldigesters }\end{array}$ \\
$\begin{array}{l}\text { Increased cecal short chain fatty acids (possible } \\
\text { mainly acetate) }\end{array}$ & $\begin{array}{c}\text { Fermented milk consumption may lead to altered } \\
\text { colonic microbial flora }\end{array}$ \\
$\begin{array}{c}\text { Colonic adaptation with prolonged feeding in lactose } \\
\begin{array}{c}\text { Altered colonic metabolism in hepatic } \\
\text { encephalopathy, which may affect entire colon }\end{array}\end{array}$ & \\
\hline
\end{tabular}


It is felt that oral calcium supplements in clinical trials did not provide equimolar concentrations of phosphates and that this omission might have influenced results. Hence, the quantity as well as the form of dairy consumption (see below) can introduce bias.

In addition, there may be other factors to consider. Of 29 reports reviewed $(20,34,183,192-217)-18$ case-controlled (20,194,196-200,202,205-207,210-212,214-217), eight cohort $(34,193,195,201,203,204,208,209)$ and three population surveys $(183,192,213)-16$ have shown odds ratios of less than 1 for some form of dairy consumption when evaluated for colon $(194,195,198,200-203)$, rectal (204) or colorectal $(20,183,192,193,196,197,199)$ carcinoma or large adenoma (205). Six of these studies achieved statistical significance $(193,196-198,202,205)$; however, four considered dietary calcium, vitamin D or milk, while two found significance for fermented products only $(202,205)$. Eight of the studies showed no influence for dairy products, calcium or vitamin D effect (34,206-212). However, in one, yoghurt consumption was inversely but significantly associated with CRC (206) and in another, only adenomas were evaluated (209). Five studies yielded an odds ratio of greater than 1 (213-217); it was statistically significant in three studies, for either dairy $(215,216)$ or dietary calcium $(214)$.

Boutron et al (205) suggested that there may be a threshold level of calcium that must be consumed to show inverse associations with CRC beyond which no further effect or even a direct association may be found. This group felt that, in temperate climates a deficiency of calcium intake is more likely and, therefore, an inverse association is more easily recognized. A similar sentiment was expressed regarding sun exposure and vitamin D ingestion in temperate, compared with equatorial, regions $(185,218)$.

Another potential factor only alluded to by some authors $(183,205)$ is the distribution of study subjects who are genetically lactose maldigesters. Although not likely to be an important issue in studies emanating from areas of relatively homogenous populations in temperate climates, the proportion of genetically lactose maldigesters may be important in other studies emanating from areas with a more heterogeneous population. In particular, western diets that stress the importance of dairy products may influence their consumption even in some lactose maldigesters. In such subjects, the issue of colonic adaptation may become relevant. Furthermore, if such subjects do not consume quantitatively as much dairy products as the indigenous population and yet have a lower risk for CRC, differences between patients and controls can become obscured. Such a bias may have played a role in some studies emanating from areas with a heterogenous population $(207,211)$. The influence of a low dairy consuming colonically adapted population could similarly bias studies showing direct association. Patients who are not lactose maldigesters may consume more dairy products habitually, preventing a fair comparison between cases and controls. As a result, such a bias may have affected three studies showing an increased risk for dairy consumption in countries closer to the equator $(214,215,217)$.
Studies on dairy foods and IBD are somewhat conflicting as well. A recent review by Mishkin (219) clearly summarized relevant data on dairy consumption and practices of dietary counselling in IBD. Some of the salient features will be reiterated here. In general, physicians often advise patients to avoid dairy products during an active phase of IBD. Many physicians may also recommend a diet reduced in dairy products during remission. The rationale for this recommendation is based on a number of studies showing poor outcomes when milk is not restricted. In 1961 Truelove (220) reported that milk can induce UC, possibly due to milk allergy, and later Wright and Truelove (221) found that about 20\% of UC patients may be sensitive to milk. It was subsequently found that patients, especially those with $\mathrm{CD}$, were less likely to have been breast-fed than controls, which suggested the development of an early sensitivity to milk products (222). Indeed, pediatric IBD patients may be more symptomatic when there is a history of cow's milk sensitivity (223), and there may be some relationship between elevated antibody levels and disease activity (224), especially in CD (225).

The other issue to consider regarding why dairy products may aggravate attacks of IBD is the role of lactose intolerance. More than 30 years ago Struthers et al (226) reported that lactose intolerance was increased in both UC and CD patients. Peña and Truelove (227) found a direct relationship between lactose intolerance and severity of UC, and Sciarretta et al (228) suggested such patients were more sensitive to lactose. Similar results were echoed more recently in a study from India (229). Pironi et al (230) reported an increased prevalence of lactose maldigestion in a group of Italian patients with CD compared with controls. Patients with intestinal resection were even more sensitive to lactose. Mishkin et al (231) found that although ethnic background accounted for most cases of lactose intolerance in both UC and $C D$, in patients with terminal ileal disease there was a higher incidence, independent of ethnic background. Another study from the same group later confirmed the observation (232).

Others reported somewhat different outcomes. Kirschner et al (233) found no increased prevalence of lactose intolerance in children with either CD or UC compared with controls. Only diffuse small bowel disease was clearly associated regularly with lactose malabsorption. Busk and colleagues (234) reported no increased prevalence of lactose intolerance in a population of Danish UC patients. Bernstein et al (235) presented findings similar to those of Mishkin et al: in UC patients, age and ethnicity could account for lactose intolerance. Park et al (236) from Scotland observed that only two of 62 patients, of whom $70 \%$ had small bowel involvement, had hypolactasia. Lobley et al (237) examined the problem of lactose intolerance in IBD by a different method - from blood glucose or breath hydrogen measurements. These authors looked at the urinary excretion of monosaccharides and lactose in different conditions. In their study the percentage of urinary lactose was significantly increased both in subjects with lactose intolerance and in celiac sprue 
patients compared with controls. However in CD patients, the slight urinary percentage increase was not significantly different from that of normals, while in UC patients there was significantly less lactose excreted (237).

There may be another theoretical reason to consider lactose maldigestion in CD. In most conditions of lactose intolerance, symptoms may be modified by reducing the rate of delivery across the ileocecal valve. Indeed, foods that retard intestinal transit may be better tolerated $(238,239)$. The use of loperamide, which retards intestinal transit, has been shown to reduce symptoms of lactose intolerance (240). In children with active $\mathrm{CD}$, a marked (two-to sixfold) increase in oral cecal transit time was demonstrated, which improved in remission (241). In the study of Mishkin et al (232) the transit time measured during lactose breath hydrogen was faster than expected for controls. Because undigested lactose should increase intestinal transit (reduced time), the above noted discrepancy should be evaluated further. Mishkin et al suggested that true lactase insufficiency or bacterial overgrowth could not be addressed by their study.

\section{SUMMARY AND CONCLUSIONS}

This review attempts to link some epidemiological and pathogenic features of CRC and IBD, primarily to emphasize possible similar environmental predisposition to these diseases. The link is based on similar geographic distribution even to the extent of existing common origin clusters (such as in central Europe) and a possible parallel shift in incidence with changing economics. In both groups of diseases, genetic predisposition, possible environmental exposure and lower intestinal bacterial ecology likely play important pathogenetic roles. As well, the integrity of the mucosal protective mechanisms is disturbed in those with IBD. However, host reactions may differ significantly at different times of life. In the case of CRC, progressive genetic alterations lead to increasing loss of control of cellular proliferation. Depending on which system is affected - the familial adenomatous polyposis family of chromosomal alterations, mismatch repair gene alterations or phenotype of lipoprotein $\mathrm{E}$ - the ultimate cancer site is determined. In IBD, different immunological abnormalities are incurred in CD and UC. The recurrent bouts of attacks may be determined by host factors, inability to reign in abnormal immune cascades or environmental factors that certainly include infections, external medications such as nonsteroidal anti-inflammatory drugs, or antibiotics and, in some, diet or other unknown toxins. The CRC and IBD colitides again converge in chronic cases where progressive loss of control of colonocyte proliferation abetted by IBD leads to early neoplasia.

Within the context of colonic environmental influences, we reviewed some of the existing literature on the impact of diet and its interaction with colonic microflora on the diseases under discussion. Specifically we also reviewed the possible impact of dairy consumption and tried to draw similarities between the effects of lactose and other disaccharides with fibre.

The conclusions drawn from this review regarding the role of fibre and dairy products in CRC and IBD are that their benefits are not clearly proven. In CRC, however, high fibre likely has a protective effect. In IBD the effects are less evident and controversial. Possible site-specific benefits, such as in 'colon only' disease, have not been well defined. Similarly, there are limited studies on the effects of individual fibres (eg, wheat bran).

In CRC the impact of dairy consumption may be confused by three intervening biases: a possible dose effect of calcium; the amount of sun exposure of study subjects; and the level of colonic bacterial/metabolic adaptation in studies emanating from regions of heterogeneous populations. In addition, fermented dairy products with live lactobacillus may have independent benefits.

In IBD dairy consumption may be instrumental in initiating or propagating disease in a segment of patients. With the exception of patients with small bowel CD, however, lactose maldigestion or intolerance is not likely increased in IBD patients beyond ethnic expectations. Importantly, the role of dairy consumption in CRC formation in IBD has not been explored.

It seems clear that colonic environmental changes can trigger CRC, IBD or CRC in IBD. The events leading to disease initiation need not be different in these diseases. After all, 20 years ago no one considered that peptic ulcer, gastric carcinoma and some gastric lymphomas may be etiologically linked to the same infectious agent. Currently, the predominant view is that control of colonic ecology by manipulating bacteria or bacterial metabolism has some benefit in controlling these diseases.

To this end, all three disaccharides - lactulose (242), lactitol and lactose (in lactose maldigesters) and lactobacilli are candidate substances for clinical trials in IBD colitides and CRC. Future studies should evaluate a possible dietetic role in familial polyposis syndromes, any protective effect against CRC in IBD and a maintenance role in IBD colitides. In conjunction, studies could also evaluate the possible value of monitoring fecal beta-galactosidase levels as an indicator of CRC risk or as a predictor of IBD relapse.

ACKNOWLEDGEMENTS: I thank Blanka Glowacki and Elizabeth Brier for expert library assistance, and Florence Lurie for devoted assistance in preparing this manuscript.

\section{REFERENCES}

1. Sartor RB. Current concepts of the etiology and pathogenesis of ulcerative colitis and Crohn's disease. Gastroenterol Clin North Am 1995;24:475-507.

2. Rhodes JM. Colonic mucus and mucosal glycoproteins: the key to colitis and cancer. Gut 1989;30:1660-6.

3. Wright NA, Poulsom R, Stamp G, et al. Trefoil gene expression in gastrointestinal epithelial cells in inflammatory bowel disease. Gastroenterology 1993;104:12-20.

4. McCafferty DM, Mudgett JS, Swain MG, Kubes P. Inducible nitric oxide synthase plays a critical role in resolving intestinal inflammation. Gastroenterology 1997;112:1022-7.

5. Sandler RS. Epidemiology and risk factors for colorectal cancer. Gastroenterol Clin North Am 1996;25:717-35.

6. Bufill JA. Colorectal cancer: Evidence for distinct genetic categories 
based on proximal distal tumor location. Ann Intern Med 1990;113:779-88.

7. Correa P, Haenszel W. The epidemiology of large bowel cancer. Adv Cancer Res 1978;26:1-141.

8. Weisburger JH. Causes, relevant mechanisms and prevention of large bowel cancer. Semin Oncol 1991;18:316-36.

9. Herrera L, Kakati S, Gibas L, et al. Brief clinical reports: Gardner syndrome in a man with an intestinal deletion of $5 \mathrm{q}$. Am J Med Genet 1986;25:473-6.

10. Groden J, Thiliveris A, Samowitz W, et al. Identification and characterization of the familial adenomatous polyposis coli gene. Cell 1991;66:589-600.

11. Hamilton S, Liu B, Parsons RE, et al. The molecular basis of Turcot's syndrome. N Engl J Med 1995;332:839-47.

12. Fearon ER, Vogelstein B. A genetic model for colorectal tumorigenesis. Cell 1990;61:759-67.

13. Marra G, Boland CR. Hereditary non polyposis colorectal cancer: the syndrome, the genes and historical perspective. J Natl Cancer Inst 1995;87:1114-25.

14. Lashner BA. Epidemiology of inflammatory bowel disease. Gastroenterol Clin North Am 1995;24:467-74.

15. Calkins BM, Mendeloff AI. The epidemiology of idiopathic inflammatory bowel disease. In: Kirsner JB, Shorter RG, eds. Inflammatory Bowel Disease, 4th edn. Baltimore; Williams \& Wilkins, 1995:31-68.

16. Gordon PH. Malignant neoplasms of the colon. In: Gordon PH, Nivatvongs S, eds. Principles and Practice of Surgery for the Colon, Rectum and Anus, 1st edn. St Louis: Quality Medical Publishing Inc, 1992:501-90.

17. Fellows IW, Mayberry JF, Holmes GKT. Crohn's disease in West Indians. Am J Gastroenterol 1988;83:752-5.

18. Salim AFM, Walker-Smith JA. Chronic inflammatory bowel disease in the children of Indian subcontinent immigrants living in Britain. Gut 1990;31:A1188-9.

19. Roth MP, Petersen GM, McElree C, Feldman E, Rotter JI. Geographic origins of Jewish patients with inflammatory bowel disease. Gastroenterology 1989;97:900-4.

20. Pickle LW, Greene MH, Ziegler RG, et al. Colorectal cancer in rural Nebraska. Cancer Res 1984;44:363-9.

21. Carethers JM. The cellular and molecular pathogenesis of colorectal cancer. Gastroenterol Clin North Am 1996;25:737-54.

22. Lipkin M. Phase 1 and phase 2 proliferative cells in diseases leading to colon cancer. Cancer 1974;34:878-88.

23. Kuramoto S, Mimura T, Yamasaki K, et al. Flat cancers do develop in the polyp-free large intestine. Dis Colon Rectum 1997;40:534-42.

24. Terpstra DI, van Blankenstein M, Dees J, Eilers GAM. Abnormal pattern of cell proliferation in the entire colonic mucosa of patients with colon adenoma or cancer. Gastroenterology 1987;92:704-8.

25. Deschner E, Lipkin M. Proliferative patterns in colonic mucosa in familial polyposis. Cancer 1975;35:413-8.

26. Holt PR, Yeh RY. Colonic proliferation is increased in senescent rats. Gastroenterology 1988;95:1556-63.

27. Vogelstein B, Fearon ER, Hamilton SR, et al. Genetic alteration during colorectal tumor development. N Engl J Med 1988;319:525-32.

28. Lynch HT, Smyrk TC, Watson P, et al. Genetic natural history, tumor spectrum and pathology of hereditary non polyposis colorectal cancer: an updated review. Gastroenterology 1993;104:1535-49.

29. Aarnio M, Mecklin JP, Aaltonen LA, Nystrom-Lahti M, Jarvinen HJ. Life-time risks of different cancers in hereditary non-polyposis colorectal cancer (HNPCC) syndrome. Int J Cancer 1995;64:430-3.

30. Liberman V, Nyska A, Kashtan H, Zajicek G, Lubin F, Rozen P. Differing proliferative responses in proximal and distal colons of growing rats fed food eaten by adenoma patients. Dig Dis Sci 1996;41:1057-64.

31. Kervnian K, Sodervik H, Makela J, et al. Is the development of adenoma and carcinoma in proximal colon related to apolipoprotein $\mathrm{E}$ phenotype? Gastroenterology 1996;110:1785-90.

32. Burkitt DP. Epidemiology of cancer of the colon and rectum. Cancer 1971;28:3-13.

33. Cummings JH, Bingham SA, Heaton KW, Eastwood MA. Fecal weight, colon cancer risk and dietary intake of nonstarch polysaccharides (dietary fibre). Gastroenterology 1992;103:1783-9.

34. Willet WC, Stampfer MJ, Colditz GA, Rosener BA, Speizer FE. Relation of meat, fat and fibre intake to the risk of colon cancer in a prospective study among women. N Engl J Med 1990;323:1664-72.
35. Reddy BS. Chemo prevention of colon cancer by dietary fatty acids. Cancer Metastasis Rev 1994;3:285-302.

36. Anti M, Marra G, Armelao F, et al. Effects of $\omega-3$ fatty acids on rectal mucosal cell proliferation in subjects at risk for colon cancer. Gastroenterology 1992;103:883-91.

37. Bertram HP, Gostner A, Scheppach W, et al. Effects of fish oil on rectal cell proliferation mucosal fatty acids and prostaglandin $\mathrm{E}_{2}$ release in healthy subjects. Gastroenterology 1993;105:1317-22.

38. Read NW. Dietary fibre and the gut: action in gastrointestinal disorders. In: Sleisinger MH, Fordtran JS, eds. Gastrointestinal Disease: Pathophysiology Diagnosis Management. Philadelphia: WB Saunders Co, 1993:2097-108.

39. Royall D, Wolever TMS, Jeejeebhoy KN. Clinical significance of colonic fermentation. Am J Gastroenterol 1990;85:1307-12.

40. Hill MJ, Drasar BS, Aries V, et al. Bacteria and etiology of cancer of large bowel. Lancet 1971;ii:95-100.

41. Aries V, Crowther JS, Drasar BS, Hill MJ, Williams REO. Bacteria and etiology of cancer of the large bowel. Gut 1969;10:334-5.

42. Goldberg MJ, Smith JW, Nichols RL. Comparison of the fecal microflora of Seventh-Day Adventists with individuals consuming a general diet. Implications concerning colonic carcinoma. Ann Surg 1977;186:97-100.

43. Watne AL, Lai HYL, Mance T, Core S. Fecal steroids and bacterial flora in patients with polyposis coll. Am J Surg 1976;131:42-6.

44. Hill MJ. Bacteria and the etiology of colonic cancer. Cancer 1974;34:814-8.

45. Winder EL, Reddy BS. Metabolic epidemiology of colorectal cancer. Cancer 1974;34:801-6.

46. Klein RS, Recco RA, Catalano MT, et al. Association of Streptococcus bovis with carcinoma of the colon. N Engl J Med 1977;297:800-2.

47. Dubrow R, Edberg S, Wikfors E, Callan D, Trancale F. Fecal carriage of Streptococcus bovis and colorectal adenoma. Gastroenterology 1991;101:721-5.

48. Pique JM, Pallares M, Cuso E, Villar-Bonet J, Ganull MA. Methane production and colon cancer. Gastroenterology 1984;87:601-5.

49. Bayerdorffer E, Mannes J, Richter WO, et al. Increased serum deoxycholic acid levels in men with colorectal adenomas. Gastroenterology 1993;104:145-51.

50. Summerton J, Flynn M, Cooke T, Taylor I. Bile acid receptors in colorectal cancer. Br J Surg 1983;70:549-51.

51. Giavannucci E, Colditz GA, Stampfer MB. A meta-analysis of cholecystectomy and risk of colorectal cancer. Gastroenterology 1993;105:130-41.

52. Galloway DJ, Owen RW, Jarrett F, et al. Experimental colorectal cancer: the relationship of diet and fecal bile acid concentration to tumour induction. Br J Surg 1986;73:233-7.

53. Roberton AM. Roles of endogenous substances and bacteria in colorectal cancer. Mutation Res 1993;290:71-8.

54. Kahl-Rainer P, Sedrevy R, Marian B. Protein kinase C tissue localization in human colonic tumours suggest a role for adenoma growth control. Gastroenterology 1996;110:1753-9.

55. Cummings JH. Short chain fatty acids in the human colon. Gut 1981;22:763-79.

56. Arola H, Tamm A. Metabolism of lactose in the human body. Scand J Gastroenterol 1994;202:21-5.

57. Roediger WEW. Utilization of nutrients by isolated epithelial cells of the rat colon. Gastroenterology 1982;83:424-9.

58. Cherbury C, Darcy-Vrillon B, Morel MT, Pegorier JP, Duee PH. Effect of germ free state on the capacities of isolated rat colonocytes to metabolize N-butyrate glucose and glutamine. Gastroenterology 1995;109:1890-9.

59. Freeman HJ. Effects of differing concentrations of sodium butyrate on dimethylhydrazine induced rat intestinal neoplasia. Gastroenterology 1986;91:596-602.

60. Sakamoto J, Nakaji S, Sugawara K, Iwane S, Munakata A. Comparison of resistant starch with cellulose diet on 1,2-dimethylhydrazine induced colonic carcinogenesis in rats. Gastroenterology 1996;110:116-20.

61. Van Monster IP, Nagengast FM. The role of carbohydrate fermentation in colon cancer prevention. Scand J Gastroenterol 1993;28(Suppl 200):80-6.

62. Williams AC, Hague A, Manning AM, Van der Stappen JWJ, Paraskeva C. In vitro models of human colorectal cancer. Cancer Surv 1993;16:15-29.

63. Hass R, Busche R, Luciano L, Reale E, Engelhardt W. Lack of butyrate 
is associated with inducation of Bax and subsequent apoptosis in the proximal colon of guinea pig. Gastroenterology 1997;112:875-81.

64. Hague A, Singh B, Paraskeva C. Butyrate acts as a survival factor for colonic epithelial cells: further fuel for the in vivo versus in in vitro debate. Gastroenterology 1996;112:1036-40.

65. Fleiszer D, Murray D, MacFarlane J, Brown RA. Protective effect of dietary fibre against chemically induced bowel tumours in rats. Lancet 1978;i:552-3.

66. Freeman HJ, Spiller GA, Kim YS. A double blind study on the effect of purified cellulose fiber on 1,2-dimethylhydrazine-induced rat colonic neoplasia. Cancer Res 1978;38:2912-7.

67. McIntyre A, Gibson PR, Young GP. Fermentation products of dietary fiber and protection against large bowel cancer in a rat model. Gut 1993;34:386-91.

68. Cruse JP, Lewin MR, Clark CG. Failure of bran to protect against experimental colon cancer in rats. Lancet 1978;ii:1278-9.

69. Jacobs LR. Enhancement of rat colon carcinogenesis by wheat bran consumption during the stage of 1,2-dimethylhydrazine administration. Cancer Res 1983;43:4057-61.

70. Jensen OM, Maclennan R. Dietary factors and colorectal cancer in Scandinavia. Isr J Med Sci 1979;15:329-34.

71. Minowa M, Bingham S, Cummings JH. Dietary fibre intake in Japan. Hum Nutr Appl Nutr 1983;371:113-9.

72. Stefansson T, Ekbom A, Sperèn P, Pahlman L. Increased risk of left sided colon cancer in patients with diverticular disease. Gut 1993;34:499-502.

73. Thornton JR, Dryden A, Kelleher J, Losowsky MS. Super-efficient starch absorption - a risk factor for colonic neoplasia. Dig Dis Sci 1987;32:1088-91.

74. Odes HS. Wheat and nonwheat dietary fibers. J Clin Gastroenterol 1987;9:131-4.

75. McIntyre A, Gibson PR, Young GP. Butyrate production from dietary fibre and protection against large bowel cancer in a rat model. Gut 1993;34:386-91.

76. Korpela JT, Korpela R, Adlercreutz H. Fecal bile acid metabolism pattern after administration of different types of bread. Gastroenterology 1992;103:1246-53.

77. Jacobs LR. Relationship between dietary fiber and cancer: Metabolic physiologic, and cellular mechanisms. Proc Soc Exp Biol Med 1986;183:299-310.

78. Howe GR, Benito E, Castelleto R, et al. Dietary intake of fiber and decreased risk of cancers of the colon and rectum: Evidence from the combined analysis of 13 case-control studies. J Natl Cancer Inst 1992;84:1887-96.

79. Kirsner JB. Crohn's disease: Yesterday, today, and tomorrow. Gastroenterology 1997;112:1028-30.

80. Sartor RB. Cytokines in intestinal inflammation: pathophysiological and clinical considerations. Gastroenterology 1994;106:533-9.

81. Duerr RH. Genetics of inflammatory bowel disease. Inflam Bowel Dis 1996;2:48-60.

82. Eliakim R, Rachmilewitz D. Inflammatory bowel disease: The asthma of the intestine. Inflam Bowel Dis 1996;2:122-32.

83. Wolfe BM, Cherry JD. Hemorrhage from cecal ulcers of cytomegalovirus infection report of a case. Ann Surg 1973;177:490-4.

84. Vantrappen G, Agg HO, Ponette E, Geboes K, Bertrand PH. Yersinia enteritis and enterocolitis: gastroenterological aspects. Gastroenterology 1977;72:220-7.

85. Penna FJ. Blastomycosis of the colon resembling clinically ulcerative colitis. Gut 1979;20:896-9.

86. Blaser MJ, Parons RB, Wang WLL. Acute colitis caused by Campylobacter fetus ss jejuni. Gastroenterology 1980;78:448-53.

87. Vender RJ, Malignani P. Salmonella colitis presenting as a segmental colitis resembling Crohn's disease. Dig Dis Sci 1983;28:848-51.

88. Orholm M, Munkholm P, Langholz E, Nielsen OH, Sorensen TIA, Binder V. Familial occurrence of inflammatory bowel disease. N Engl J Med 1991;324:84-8.

89. Lashner BA, Evans A, Kirsner JB, Hannauer SB. Prevalence and incidence of inflammatory bowel disease in family members. Gastroenterology 1986;91:1396-400.

90. VanKruiningen HJ, Colombel JF, Cartun RW, et al. An in depth study of Crohn's disease in two French families. Gastroenterology 1993;104:351-60.

91. Aisenberg J, Janowitz HD. Cluster of inflammatory bowel disease in three close college friends. J Clin Gastroenterol 1993;17:18-20.

92. Yang H, Rotter JI, Toyoda H, et al. Ulcerative colitis: A genetically heterogeneous disorder defined by genetic (HLA class II) and subclinical (antineutrophil cytoplasmic antibodies) markers. J Clin Invest 1993;92:1080-4.

93. Vasiliauskas EA, Pevy SE, Landers CJ, et al. Perinuclear antineutrophil cytoplasmic antibodies in patients with Crohn's disease define a clinical subgroup. Gastroenterology 1996;110:1810-9.

94. May GR, Sutherland LR, Meddings JB. Is small intestinal permeability really increased in relatives of patients with Crohn's disease. Gastroenterology 1993;104:1627-32.

95. Podolsky DK, Isselbacher KJ. Glycoprotein composition of colonic mucosa specific alterations in ulcerative colitis. Gastroenterology 1984;87:991-8

96. Szilagyi A, Gerson M, Mendelson J, Yusuf NA. Salmonella infections complicating inflammatory bowel disease. J Clin Gastroenterol 1985;7:251-5.

97. Wurzelmann JI, Lyles CM, Sandler RS. Childhood infections and the risk of inflammatory bowel disease. Dig Dis Sci 1994;39:555-60.

98. Gebhard RL, Greenberg HB, Singh PH Sharp HL, Kaplan L, Kapikian AZ. Acute viral enteritis and exacerbations of inflammatory bowel disease. Gastroenterology 1982;83:1207-9.

99. Sidi S, Graham JH, Razvi SA, Banks PA. Cytomegalovirus infection of the colon associated with ulcerative colitis. Arch Surg 1979;114:857-9.

100. Meyers S, Mayer L, Bottone E, Desmond E, Janowitz HD. Occurrence of Clostridium difficile toxin during the course of inflammatory bowel disease. Gastroenterology 1981;80:697-700.

101. Isagar B, Marman M, Whorewell PJ. Factors preceding relapse of ulcerative colitis. Digestion 1983;26:236-8.

102. Elson CO, Sartor RB, Tennyson GS, Riddell RH. Experimental models of inflammatory bowel disease. Gastroenterology 1995:109:1344-67.

103. Onderdonk AB, Bronson R, Asneros R. Comparison of Bacteroides vulgatus strains in the enhancement of experimental ulcerative colitis. Infect Immun 1987;55:835-6.

104. Johnson LD, Ausman LM, Sehgal PK, King NW Jr. A prospective study of the epidemiology of colitis and colon cancer in cotton-top Tamarins (Saguinus oedipus). Gastroenterology 1996;110:102-15.

105. Hartley MG, Hudson MJ, Swarbrick ET, et al. The rectal mucosa-associated microflora in patients with ulcerative colitis. J Med Microbiol 1992;36:96-104.

106. Gorbach SL. Intestinal microflora in inflammatory bowel disease implications for etiology. In: Kirsner JB, Shorter RG, eds. Inflammatory Bowel Disease. Philadelphia: Lea \& Febiger, 1988:51-64.

107. Favier C, Neut C, Mizon C, Cortot A, Colombel JF, Mizon J. Fecal $\beta$-D-galactosidase production and bifidobacteria are decreased in Crohn's disease. Dig Dis Sci 1997;42:817-22.

108. Rutgeerts P, Geboes K, Peeters M, et al. Effects of faecal stream diversion on recurrence of Crohn's disease in the neoterminal ileum. Lancet 1991;338:771-4

109. Van de Merwe JP, Schroder F, Wesnick F, Hanenberg MP. The obligate anaerobic faecal flora of patients with Crohn's disease and their first degree relatives. Scand J Gastroenterol 1988;23:1125-31.

110. Onderdonk AB, Hermos JA, Dzink JL, Bartlett JG. Protective effect of metronidazole in experimental ulcerative colitis. Gastroenterology 1978;74:521-6.

111. Sutherland L. Double blind placebo controlled trial of metranidazole in Crohn's disease. Gut 191;32:1071.

112. Peppercorn MA. Are antibiotics useful in the management of nontoxic severe ulcerative colitis? J Clin Gastroenterol 1993;17:14-7.

113. Roediger WEW. The starved colon-diminished mucosal nutrition diminished absorption and colitis. Dis Colon Rectum 1990;33:858-62.

114. Rabassa AA, Rogers AI. The role of short chain fatty acid metabolism in colonic disorders. Am J Gastroenterol 1992;87:419-23.

115. Chapman MAS, Grahn MF, Boyle MA, Hutton M, Rogers J, Williams NS. Butyrate oxidation is impaired in the colonic mucosa of sufferers of quiescent ulcerative colitis. Gut 1994;35:73-6.

116. Stonerook MJ, Tefend KS, Sherma HM, Peck OC, Wood JD. Fecal short-chain fatty acids associated with inflammation in cotton-top Tamarin model for idiopathic colitis. Dig Dis Sci 1996;41:1618-24.

117. Vernia P, Caprilli R, Latella G, et al. Fecal lactate and ulcerative colitis. Gastroenterology 1988;95:1564-8.

118. Fallingborg J, Christensen L, Lacobsen BA, Rasmussen SN. Very low intraluminal colon $\mathrm{pH}$ in patients with active ulcerative colitis. Dig Dis Sci 1993;38;1989-93.

119. Perman JA, Modler S, Olson AC. Role of $\mathrm{pH}$ in production of 
hydrogen from carbohydrates by colonic bacterial flora. J Clin Invest 1981;67:643-50.

120. Roediger WEW, Duncan A, Kapaniris O, Millard S. Reducing sulfur compounds of the colon impair colonocyte nutrition: implications for ulcerative colitis. Gastroenterology 1993;104:802-9.

121. Steinhart AH, Brzezinski A, Baker JP. Treatment of refractory ulcerative proctosigmoiditis with butyrate enemas. Am J Gastroenterol 1994;89:179-83.

122. Senagore AJ, MacKeigan JM, Schuder M, Ebrom JS. Short-chain fatty acid enemas: A cost-effective alternative in the treatment of non-specific proctosigmoiditis. Dis Colon Rectum 1992;35:923-7.

123. Scheppach W and German Austrian SCFA study group. Treatment of distal ulcerative colitis with short-chain fatty acid enemas. A placebo controlled trial. Dig Dis Sci 1996;41:2254-9.

124. Itzkowtiz SH. Inflammatory bowel disease and cancer. Gastroenterol Clin North Am 1997;26:129-39.

125. Brentnall TA, Haggitt RC, Rabinovitch PS, et al. Risk and natural history of colonic neoplasia in patients with primary sclerosing cholangitis and ulcerative colitis. Gastroenterology 1996;110:331-8.

126. Loftus EV Jr, Sandborn WJ, Tremaine WJ, et al. Risk of colorectal neoplasia in patients with primary sclerosing cholangitis. Gastroenterology 1996;110:432-40.

127. Eastwood GL, Trier JS. Epithelial cell renewal in cultured rectal biopsies in ulcerative colitis. Gastroenterology 1973;64:383-90.

128. Sarafini EP, Apkirk A, Chambers TC. Rate and pattern of epithelial cell proliferation in ulcerative colitis. Gut 1981;22:648-52.

129. Lehy T, Mignon M, Abitbol JL. Epithelial cell proliferation in the rectal stump of patients with ileorectal anastomosis for ulcerative colitis. Gut 1983:24:1048-56.

130. Hill MJ, Melville DM, Lennard-Jones JE, Neale K, Ritchie JK. Faecal bile acids, dysplasia and carcinoma in ulcerative colitis. Lancet 1987;ii:185-6.

131. Ejderhamn J, Rafter JJ, Strandvik B. Faecal bile acid excretion in children with inflammatory bowel disease. Gut 1991;32:1346-51.

132. D'Argenio G, Cosenza V, Delle Cave M, et al. Butyrate enemas in experimental colitis and protection against large bowel cancer in rat model. Gastroenterology 1996;110:1727-34.

133. Brentnall TA, Rubin CE, Crispin DA, et al. A germline substitution in the human $\mathrm{MSH}_{2}$ gene is associated with high-grade dysplasia and cancer in ulcerative colitis. Gastroenterology 1991;109:151-5.

134. Yin J, Harpaz N, Tong Y, et al. p53 point mutations in dysplastic and cancerous ulcerative colitis lesions. Gastroenterology 1993;104:1633-9.

135. Kern SE, Redston M, Seymour AB, et al. Molecular genetic profiles of colitis-associated neoplasms. Gastroenterology 1994;107:420-8.

136. Brentnall TA, Crispin DA, Rabinovitch PS, et al. Mutations in the p53 gene: An early marker of neoplastic progression in ulcerative colitis. Gastroenterology 1994;107:369-78.

137. Thornton JR, Emmett PM, Heaton KW. Diet and Crohn's disease: characteristics of the pre illness diet. Br Med J 1979;2:762-4.

138. Kasper H, Sommer H. Dietary fiber and nutrient intake in Crohn's disease. Am J Clin Nutr 1979;32:1898-901.

139. Heaton KW, Thornton JR, Emmett PM. Treatment of Crohn's disease with an unrefined-carbohydrate, fiber-rich diet. Br Med J 1979;2:764-6.

140. Davies PS, Rhodes J. Maintenance of remission in ulcerative colitis with sulphsalazine or a high-fiber diet: a clinical trial. Br Med J 1978;2:1524-5

141. Jones VA, Dickinson RJ, Workman E, et al. Crohn's disease: Maintenance of remission by diet. Lancet 1985;i:177-80.

142. Levenstein S, Pantera C, Luzi C, D'Ubaldi A. Low residue or normal diet in Crohn's disease: a prospective controlled study in Italian patients. Gut 1985;26:989-93.

143. Fischer JE, Foster GS, Abel RM, Abbott WM, Ryan JA. Hyperalimentatation as primary therapy for inflammatory bowel disease. Am J Surg 1973;125:165-75.

144. Vogel CM, Corwin TR, Baue AE. Intravenous hypersalimentation in the treatment of inflammatory diseases of the bowel. Arch Surg 1974;108:460-7.

145. Perkal MF, Seashore JH. Nutrition and inflammatory bowel disease. Gastroenterol Clin North Am 1989;18:567-78.

146. Greenberg GR, Fleming CR, Jeejeebhoy KN, Rosenberg I, Sales D, Tremaine WJ. Controlled trial of bowel rest and nutritional support in the management of Crohn's disease. Gut 1988;29:1309-15.

147. Payne-James JJ, Silk DBA. Total parenteral nutrition as primary treatment in Crohn's disease-RIP. Gut 1988;29:1304-8.
148. Cravo M, Camilo ME, Correia JP. Nutritional support in Crohn's disease which route? Am J Gastroenterol 1991;86:317-21.

149. Teahon K, Bjarnason I, Pearson M, Levi AJ. Ten years' experience with an elemental diet in the management of Crohn's disease. Gut 1990;31:1133-7.

150. Seidman EG. Nutritional inanagement of inflammatory bowel disease. Gastroenterol Clin North Am 1989;18:129-55.

151. O'Morain CA. Does nutritional therapy in inflammatory bowel disease have a primary or an adjunctive role. Scand J Gastroenterol 1990;S172:29-34.

152. Riordan AM, Hunter JD, Cowan RE, et al. Treatment of active Crohn's disease by exclusion diet: East Anglican multicenter controlled trial. Lancet 1993;342:1131-4.

153. Pearson M, Teahon K, Levi AJ, Bjarnason I. Food intolerance and Crohn's disease. Gut 1993;34:783-7.

154. Gonzalez-Huiz F, Fernandez-Banares F, Esteve-Comas M, et al. Enteral versus parenteral nutrition as adjunct therapy in acute ulcerative colitis. Am J Gastroenterol 1993;88:227-32.

155. Aslan A, Triadafilopoulos G. Fish oil fatty acid supplementation in active ulcerative colitis: A double-blind, placebo-controlled, crossover study. Am J Gastroenterol 1992;87:432-7.

156. Stenson WF, Cort D, Rodgers J, et al. Dietary supplementation with fish oil in ulcerative colitis. Ann Intern Med 1992;116:609-14.

157. Hawthorne AB, Daneshmend TK, Hawkey CJ, et al. Treatment of ulcerative colitis with fish oil supplementation: a prospective 12 month randomized controlled trial. Gut 1992;33:922-8.

158. Hawkey CJ, Dube LM, Rountree LV, et al. Trial of zileuton versus mesalazine or placebo in the maintenance of remission of ulcerative colitis. Gastroenterology 1997;112:718-24.

159. Roberts WG, Simon TJ, Berlin RG, et al. Leukotrienes in ulcerative colitis: Results of a multicenter trial of a leukotriene biosynthesis inhibitor MK591. Gastroenterology 1997;112:725-32.

160. Lashner BA, Provencher KS, Seidner DL, Knesebeck A, Brzezinski A. The effect of folic acid supplementation on the risk for cancer or dysplasia in ulcerative colitis. Gastroenterology 1997;112:29-32.

161. Uribe M, Marquez MA, Garcia-Ramos G, et al. Treatment of chronic portal-systemic encephalopathy with lactose in lactose deficient patients. Dig Dis Sci 1980;25:924-8.

162. Florent C, Flourie B, Leblond A, Rautureau M, Bernier JJ, Rambaumd JC. Influence of chronic lactulose ingestion on the colonic metabolism of lactulose in man (an in vivo study). J Clin Invest 1985;75:608-13.

163. Riggio O, Varriale M, Testore GP, et al. Effect of lactitol and lactulose administration on the fecal flora in cirrhotic patients. J Clin Gastroenterol 1990;12:433-6.

164. Bird SP, Hewitt D, Ratcliffe B, Gurr MI. Effects of lactulose and lactitol on protein digestion and metabolism in conventional germ gree animal models: relevance of the results to their use in the treatment of portosystemic encephalopathy. Gut 1990;31:1403-6.

165. Loguercio C, Abbiati R, Rinaldi M, et al. Long term effects of Enterococcus faecium SF68 versus lactulose in the treatment of patients with cirrhosis and grade 1-2 hepatic encephalopathy. J Hepatol 1995;23:39-46.

166. Terada A, Hara H, Kataoka M, Mitsuoka T. Effect of lactulose on the composition and metabolic activity of the human faecal flora. Microb Ecol Health Dis 1992;5:43-50.

167. Flourie B, Briet F, Florent C, Pellier P, Maurel M, Rambaud JC. Can diarrhea induced by lactulose be reduced by prolonged ingestion of lactulose? Am J Clin Nutr 1993;58:369-75.

168. Roediger WEW. Role of anaerobic bacteria in the metabolic welfare of the colonic mucosa in man. Gut 1980;21:793-8.

169. Trinidad TP, Wolever TMS, Thompson LU. Effect of acetate and propionate oil calcium absorption from the rectum and distal colon of humans. Am J Clin Nutr 1996;63:574-8.

170. Habte D, Sterby G, Hijalmarsson B. Lactose malabsorption in Ethiopian children. Acta Paediatr Scand 1973;62:649-54.

171. Sadre M, Karbasi K. Lactose intolerance in Iran. Am J Clin Nutr 1979;32:1948-54.

172. Hertzler S, Savaiano DA. Colonic adaptation to daily lactose feeding in lactose maldigesters reduces lactose intolerance. Am J Clin Nutr 1996;64:232-6.

173. Hertzler SR, Savaiano DA, Levitt MD. Fecal hydrogen production and consumption measurements. Response to daily lactose ingestion by lactose maldigesters. Dig Dis Sci 1997;42:348-53.

174. Briet F, Flourie B, Achour L, Maurel M, Rambaud JC, Messing B. 
Bacterial adaptation in patients with short bowel and colon in continuity. Gastroenterology 1995;109:1446-53.

175. Briet F, Achour L, Flourie B, et al. Symptomatic response to varying levels of fructo-oligosaccharides consumed occasionally or regularly. Eur J Clin Nutr 1995;49:501-7.

176. Van Berge Hennegouwen GP, Van der Werf SDJ, Ruben ATH. Effect of long term lactulose ingestion on secondary bile salt metabolism in man: potential protective effect of lactulose in colonic carcinogenests. Gut 1987;28:675-80.

177. Siigur U, Tamm A, Tammur R. The faecal SCFAs and lactose tolerance in lactose malabsorbers. Eur J Gastroenterol Hepatol 1991;3:321-4.

178. Kajs TM, Fitzgerald JA, Buckner RY, et al. Influence of a methanogenic flora on the breath $\mathrm{H}_{2}$ and symptom response to ingestion of sorbitol or oat fiber. Am J Gastroenterol 1997;92:89-94.

179. Marteau P, Rambaud JC. Potential of using lactic acid bacteria for therapy and immunomodulation in man. FEMS Microbiol Rev 1993;12:207-20.

180. Lidbeck A, Allinger UG, Orrhage KM, et al. Impact of Lactobacillus acidophilus supplements on the faecal microflora and soluble faecal bile acids in colon cancer patients. Microb Ecol Health Dis 1991;4:81-8.

181. Goldin BR, Gorbach SL. The effect of milk and lacto bacillus feeding on human intestinal bacterial enzyme activity. Am J Clin Nutr 1984;39:756-61.

182. Marteau P, Pochart P, Flourie B, et al. Effect of chronic ingestion of a fermented dairy product containing Lactobacillus acidophilus and Bifidobacterium bifidum on metabolic activities of the colonic flora. Am J Clin Nutr 1990;52:685-8.

183. International agency for research on cancer intestinal microecology group. Dietary fibre, transit time, faecal bacteria, steroids and colon cancer in two Scandinavian populations. Lancet 1977;i:207-11.

184. Lipkin M, Newmark H. Calcium and prevention of colon cancer. J Cell Biochem 1995;22:65-73.

185. Bovee-Oudenhoven IMJ, Termont DSML, Weerkamp AH, Faasen-Peters MAW, Van der Meer R. Dietary calcium inhibits the intestinal colonization and translocation of salmonella in rats. Gasteroenterology 1997;113:550-7.

186. Lipkin M, Newmark H. Effect of added dietary calcium on colonic epithelial-cell proliferation in subjects at high risk for familial colonic cancer. N Engl J Med 1985;313:1381-4

187. Rozen P, Fureman Z, Fine N, Wax Y, Ron E. Oral calcium suppresses increased rectal epithelial proliferation of persons at risk of colorectal cancer. Gut 1989;30:650-5.

188. Gregoire RC, Stern HZ, Yeung KS, et al. Effect of calcium supplementation on mucosal cell proliferation in high risk patients for colon cancer. Gut 1989;30:376-82.

189. Alder RJ, McKeown-Eyssen G, Bright-See E. Randomized trial of the effect of calcium supplementation on fecal risk factors for colorectal cancer. Am J Epidemiol 1993;138:804-14.

190. Barsoum GH, Thompson H, Neoptolemos JP, Keighly MRB. Dietary calcium does not reduce experimental colorectal carcinogenesis after small bowel resection despite reducing cellular proliferation. Gut 1992;33:1515-20.

191. Lupton JR. Dairy products and colon cancer: mechanisms of the protective effect. Am J Clin Nutr 1997;66:1065-6.

192. Teppo L, Saxén E. Epidemiology of colon cancer in Scandinavia. Isr J Med Sci 1979;15:322-8.

193. Garland C, Shekelle RB, Barrett-Connor E, et al. Dietary vitamin D and calcium and risk of colorectal cancer. A 19-year prospective study in men. Lancet 1985;i:307-9.

194. Tajima K, Tominga S. Dietary habits and gastrointestinal cancers: A comparative case-control study of stomach and large intestinal cancers in Nagoya Japan. Jpn J Cancer Res 1985;76:705-16.

195. Phillips RL, Snowdon DA. Dietary relationships with fatal colorectal cancer among Seventh-Day Adventists. J Natl Cancer Inst 1985;74:307-17.

196. Macquart-Moulin G, Riboli E, Cornée J, Charnay B, Berthezene P, Day N. Case control study on colorectal cancer and diet in Marseilles. Int J Cancer 1986;38:183-91.

197. Kune S, Kune GA, Watson LF. Case control study of dietary etiological factors: The Melbourne colorectal cancer study. Nutr Cancer 1987;9:21-42.

198. Slattery ML, Sorenson W, Ford MH. Dietary calcium intake as a mitigating factor in colon cancer. Am J Epidemiol 1988;128:504-14.
199. Young TB, Wolfe DA. Case control study of proximal and distal colon cancer and diet in Wisconsin. Int J Cancer 1988;42:167-75.

200. Lee HP, Gourley L, Duffy SW, Estève J, Lee J, Day NE. Colorectal cancer and diet in an Asian population - a case control study among Singapore Chinese. Int J Cancer 1989;43:1007-16.

201. Ursin G, Bjelke E, Heuch I, Vollset SE. Milk consumption and cancer incidence: a Norwegian prospective study. Br J Cancer 1990;61:454-9.

202. Peters RK, Pike MC, Garobrant D, Mack TM. Diet and colon cancer in Los Angeles county California. Cancer Causes Controls 1992;3:457-73.

203. Bostick RM, Potter JD, Sellers TA, McKenzie DR, Kushi LH, Folsom AR. Relation of calcium, vitamin D, and dairy food intake to incidence of colon cancer among older women. Am J Epidemiol 1993;137:1302-17.

204. Stemmerman GN, Nomura A, Chyou PH. The influence of dairy and non-dairy calcium on subsite large-bowel cancer risk. Dis Colon Rectum 1990;33:190-4.

205. Boutron M-C, Faivre J, Marteau P, Couillault C, Senesse P, Quipourt $\mathrm{V}$. Calcium, phosphorus, vitamin D, dairy products and colorectal carcinogenests: a French case-control study. Br J Cancer 1996;74:145-51.

206. Kampman E, Van't Veer P, Hiddink GJ, vanAken-Schneijder P, Kok FJ, Hermus RJJ. Fermented dairy products, dietary calcium and colon cancer: A case-control study in the Netherlands. Int J Cancer 1994;59:170-6.

207. Negri E, LaVecchia C, D'Avanzo B, Franceschi S. Calcium, dairy products and colorectal cancer. Nutr Cancer 1990;13:255-62.

208. Wu AH, Paganini-Hill RK, Henderson RBE. Alcohol, physical activity and other risk factors for colorectal cancer: A prospective study. Br J Cancer 1987;55:687-94.

209. Kampman E, Giovannucci E, Van't Veer P, et al. Calcium, vitamin D, dairy foods and the occurrence of colorectal adenomas among men and women in two prospective studies. Am J Epidemiol 1994;139:16-29.

210. Heilburn LK, Hankin IH, Nomura AMY, Stemmermann GN. Colon cancer and dietary fat, phosphorus and calcium in Hawaiian-Japanese men. Am J Clin Nutr 1986:43:306-9.

211. Miller AB, Howe GR, Jain M, Cralb KJP, Harrison L. Food items and food groups as risk factors in a case-control study of diet and colorectal cancer. Int J Cancer 1983;32:155-61.

212. Graham S, Marshall J, Haughey B, et al. Dietary epidemiology of cancer of the colon in western New York. Am J Epidemiol 1988;128:490-503.

213. Serra-Majem L, LaVecchia C, Ribas-Barba L, et al. Changes in diet and mortality from selected cancers in Southern Mediterranean countries 1960-1989. Eur J Clin Nutr 1993;47:S25-34.

214. Benito E, Stiggelbout A, Bosch FX, et al. Nutritional factors in colorectal cancer risk: a case-control study in Majorca. Int J Cancer 1991;49:161-7.

215. Benito E, Obrador A, Stiggelbout A, et al. A population-based case-control study of colorectal cancer in Majorca, dietary factors. Int J Cancer 1990;45:69-76.

216. Tuyns AJ, Kaaks R, Haelterman M. Colorectal cancer and the consumption of foods: A case control study in Belgium. Nutr Cancer 1988;11:189-204

217. Manousos O, Day NE, Trichopoulos D, Gerovassilis F, Tsonu A, Polychronopoulou A. Diet and colorectal cancer: A case control study in Greece. Int J Cancer 1983;32:1-5.

218. Heilburn LK, Nomura A. Dietary vitamin D and calcium and risk of colorectal cancer. Lancet 1985;ii:925.

219. Mishkin S. Dairy sensitivity, lactose malabsorption and elimination diets in inflammatory bowel disease. Am J Clin Nutr 1997;65:564-7.

220. Truelove SC. Ulcerative colitis provoked by milk. Br Med J 1961;1:154-60.

221. Wright R, Truelove SC. A controlled therapeutic trial of various diets in ulcerative colitis. Br Med J 1965;22:138-41.

222. Jarnerot G. Dietary factors in inflammatory bowel disease. In: Jarnerot G, Lennard-Jones J, Truelove S, eds. Inflammatory Bowel Disease. Malmö: Corona Astra, 1992:53-60.

223. Glassman MS, Newman LJ, Berezin S, Gryboski JD. Cows' milk protein sensitivity during infancy in patients with inflammatory bowel disease. Am J Gastroenterol 1990;85:838-40.

224. Lerner A, Rossi TM, Park B, Albini B, Lebenthal E. Serum antibodies to cows' milk proteins in pediatric inflammatory bowel disease: Crohn's disease vs ulcerative colitis. Acta Paediatr Scand 1989;78:81-6. 
225. Knoflach P, Park BH, Cunningham R, et al. Serum antibodies to cows' milk proteins in ulcerative colitis and Crohn's disease. Gastroenterology 1987;92:479-85.

226. Struthers JE Jr, Singleton JW, Kern F Jr. Intestinal lactase deficiency in ulcerative colitis and regional ileitis. Ann Intern Med 1965;63:221-8.

227. Peña AS, Truelove SC. Hypolactasia and ulcerative colitis. Gastroenterology 1973;64:400-4.

228. Sciarretta G, Giacobanzi G, Verri A, et al. Hydrogen breath test quantification and clinical correlation of lactose malabsorption in adult irritable bowel syndrome and ulcerative colitis. Dig Dis Sci 1984;29:1098-104.

229. Kochhar R, Mehta SK, Goenka MK, Mukherjee JJ, Rana SV, Gupta D. Lactose intolerance in idiopathic ulcerative colitis in north Indians. Ind J Med Res 1993;98:79-82.

230. Pironi L, Callegari C, Cornia GL, Lami F, Miglioli M, Barbara L. Lactose malabsorption in adult patients with Crohn's disease. Am J Gastroenterol 1990;83:1267-71.

231. Mishkin B, Yalovsky M, Mishkin S. Increased prevalence of lactose malabsorption in Crohn's disease patients at low risk for lactose malabsorption based on ethnic origin. Am J Gastroenterol 1997;92:1148-53.

232. Mishkin D, Sablauskas L, Yalovsky M, Mishkin S. $\mathrm{H}_{2}$ breath testing in 532 patients after all had been challenged with lactose $(25 \mathrm{~g})$, fructose (25g) and sorbitol (5g). Can J Gastroenterol 1996;10(Suppl A):37A.

233. Kirschner BS, DeFavaro MV, Jensen W. Lactose malabsorption in children and adolescents with inflammatory bowel disease. Gastroenterology 1981;81:829-32.
234. Busk HE, Dahlerup B, Lytzen T, Binder V, Gudmand-Hoyer E. The incidence of lactose malabsorption in ulcerative colitis. Scand J Gastroenterol 1975;10:263-5.

235. Bernstein CN, Ament A, Artinian L, Ridgeway J, Shanahan F. Milk tolerance in adults with ulcerative colitis. Am J Gastroenterol 1994;89:872-7.

236. Park RH, Duncan A, Russell R. Hypolactasia and Crohn's disease: A myth. Am J Gastroenterol 1990;85:708-10.

237. Lobley RW, Burrows PC, Warwick R, Dawson DJ, Holmes R. Simultaneous assessment of intestinal permeability and lactase tolerance with orally administered raffinose lactose and L-arabinose. Clin Sci 1990;79:175-83.

238. Read NW, Al-Janabi NIN, Bates TE, et al. Interpretation of the breath hydrogen profile obtained after ingesting a solid meal containing unabsorbable carbohydrate. Gut 1985;26:834-42.

239. Ladas S, Frydas A, Papadopoulos A, Raptis SA. Effects of a glucosidase inhibitors on mouth to caecum transit time in humans. Gut 1992;33:1246-8.

240. Szilagyi A, Salomon R, Seidman E. Influence of loperamide on lactose handling and oral caecal transit time. Aliment Pharmacol Ther 1996;10:765-70

241. Gotze H, Ptok A. Orocaecal transit time in patients with Crohn's disease. Eur J Pediatr 1993;152:193-6.

242. Liao W, Cui XS, Jin XY, Floren CH. Lactulose - a potential drug for the treatment of inflammatory bowel disease. Med Hypoth 1994:43:234-8. 


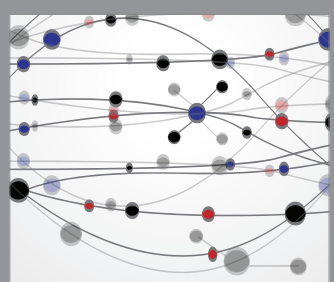

The Scientific World Journal
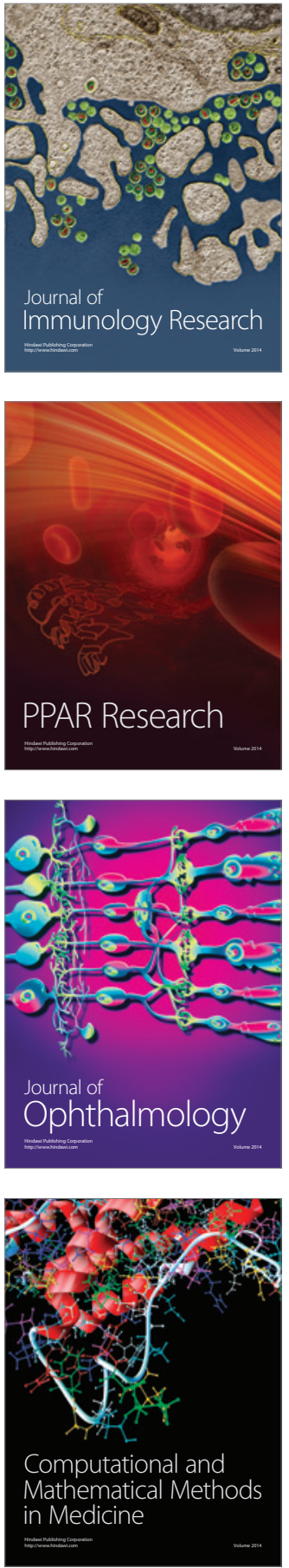

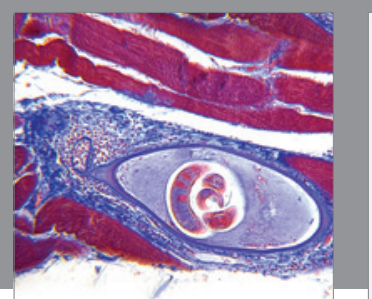

Gastroenterology Research and Practice

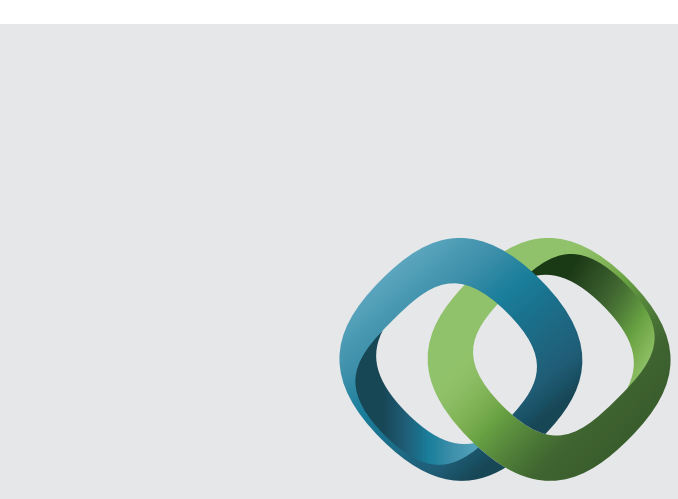

\section{Hindawi}

Submit your manuscripts at

http://www.hindawi.com
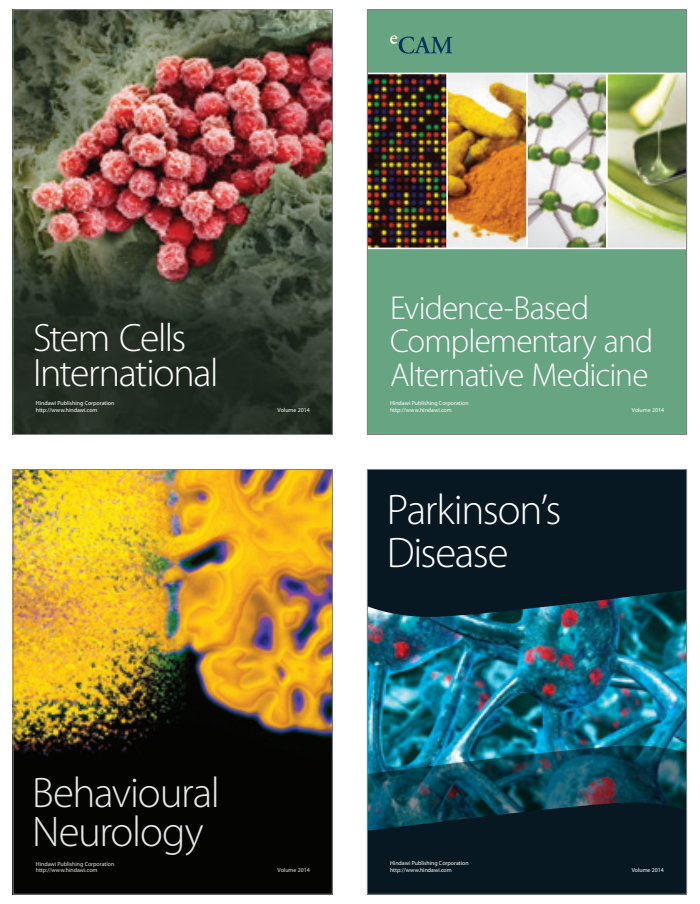
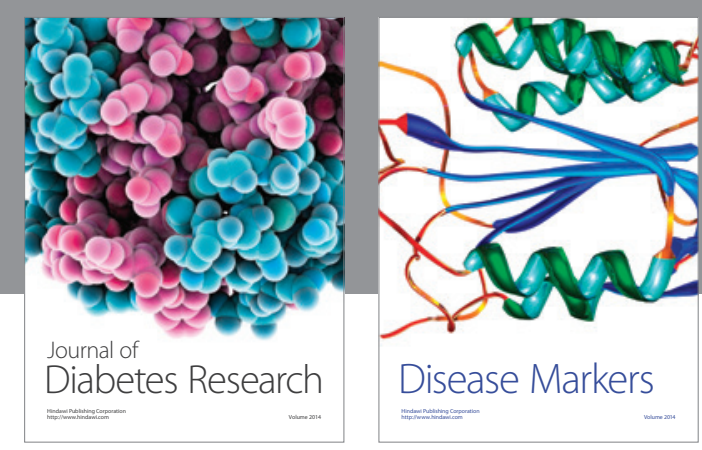

Disease Markers
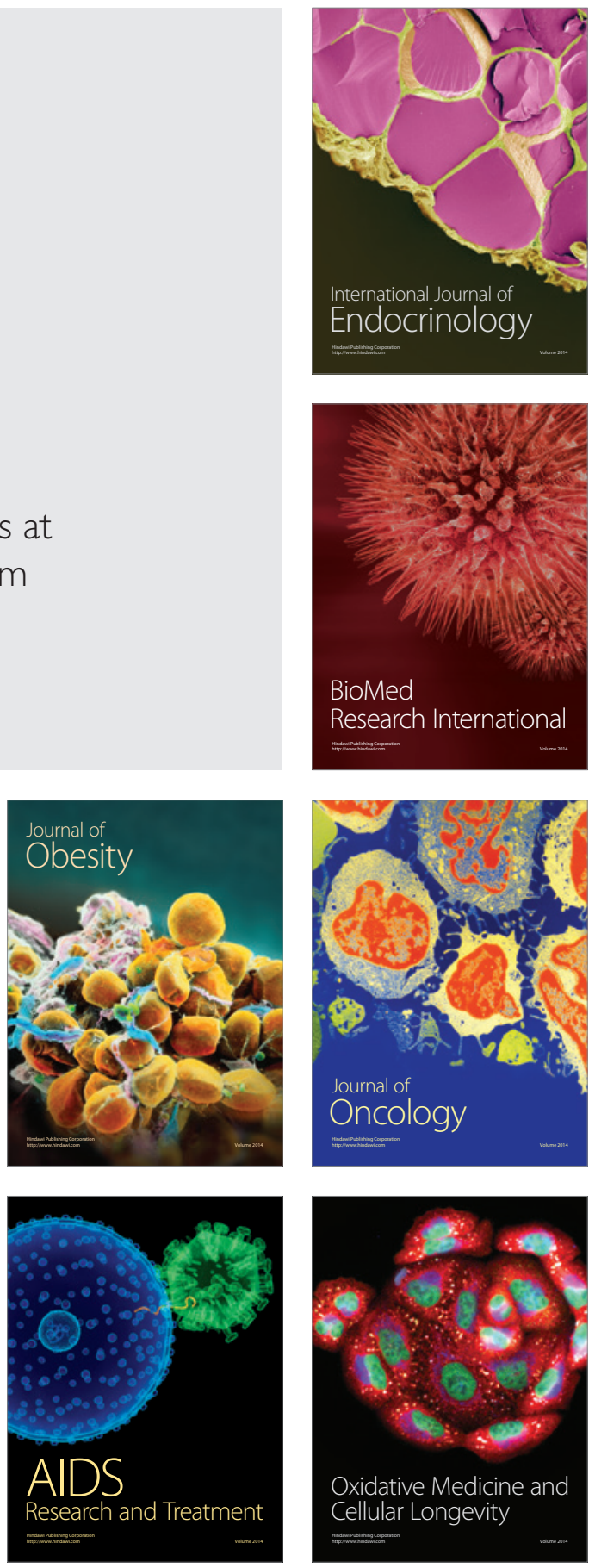